\title{
Is Foreign Aid Working? The Impact of Foreign Aid on Savings, Investment, and Economic Growth in Haiti
}

\author{
Arché Jean, Ph.D. ${ }^{1,2,3}$ \\ ${ }^{1}$ Consultant, Ministry of Economy \& Finance, Port-au-Prince, Haiti \\ ${ }^{2}$ Instructor of Finance, Académie Nationale Diplomatique et Consulaire (ANDC), 25 Ave N, Port-au-Prince, Haiti \\ ${ }^{3}$ Online Adjunct Faculty of Economics and Finance, Colorado Technical University, USA \\ Correspondence: Arché Jean, Instructor of Finance, Académie Nationale Diplomatique et Consulaire (ANDC), 25 Ave \\ N, Port-au-Prince, Haiti.
}

Received: November 25, 2014

Accepted: December 12, 2014

Available online: January 26, 2015

doi:10.11114/afa.v1i1.646

URL: http://dx.doi.org/10.11114/afa.v1i1.646

\begin{abstract}
Despite increases in foreign aid inflow to Haiti, the country remains one of the poorest in the world. Findings regarding the benefits of foreign aid have been inconsistent. The purpose of this quantitative, archival study was to examine the extent to which total foreign aid explained gross domestic savings, gross domestic investment, and GDP growth rates in Haiti from 1975 to 2010 after 3-year, 4-year, and 5-year time lags. Foreign aid was disaggregated into grants and concessional loans. Data were drawn from the World Bank, the International Monetary Fund, and the Organization for Economic Cooperation and Development from 1970 to 2010. To analyze the extent to which total foreign aid predicted gross domestic savings and gross domestic investment, weighted least squares regression analyses were conducted, with per capita income, interest rates, and inflation rates as covariates. To examine the degree to which total foreign aid predicted GDP growth rates, multiple linear regression analyses were conducted, with consumption, government spending, gross domestic investment, and net trade balance as covariates. Foreign aid did not predict gross domestic savings for 3-year time lag, $F(5,30)=1.32, p=.28$; 4-year time lag, $F(5,30)=1.24, p=.32$, or 5-year time lag, $F(5,30)$ $=1.30, p=.15$. Foreign aid did not predict gross domestic investment for 3 -year time lag, $F(5,30)=1.49, p=.22$; 4-year time lag, $F(5,30)=1.73, p=.16$, or 5-year time lag, $F(5,30)=2.29, p=.07$. Foreign aid did not predict GDP growth rates for 3-year time lag, $F(6,29), p=.44$; 4-year time lag, $F(6,29)=1.11, p=.38$, or 5-year time lag $F(6,29)=$ $0.83, p=.56$. Findings showed that foreign aid inflows to Haiti have not predicted improved economic development. Future research should focus on determining the relationship between foreign aid and government investment in infrastructure, education, health, and social projects. The discussion should shift from whether foreign aid flows to developing countries are effective to how to make the allocation of foreign aid inflows more effective. The result would be improved use of the inflow of foreign aid and improved economic and social progress in developing nations.
\end{abstract}

Keywords: foreign aid, economic growth, savings, investment, aid effectiveness, developing countries, economic policy.

\section{Introduction and Context}

\subsection{Introduction}

Foreign aid has become a reliable means of promoting development, relieving suffering, and alleviating poverty in developing and underdeveloped nations (Prokopijevic, 2006). Of all such countries, the Republic of Haiti has received more support from the international community than any other country (Seintenfus, 2010). Haiti relies on foreign aid to balance its operating budget, to finance its development projects, and to compensate for its low investment level due to poor savings rates (Bazin, 2008; Buss \& Gardner, 2008). Since 2000, Haiti has received more than $\$ 4$ billion dollars in direct aid.

Nevertheless, foreign aid to Haiti has failed to improve the standard of living within that country (Buss \& Gardner, 2008). Since 1975, more precisely over the last three decades, development has been minimal and economic growth has remained stagnant. Haiti has continued to have the lowest per capita income, remaining one of the poorest nations in the world (Buss \& Gardner, 2008). Haiti has also continued to have the highest child mortality rate, the highest illiteracy 
rate, and the lowest life expectancy rate in the region (Diego, 2010; McNulty, 2011). To understand the failure of foreign aid to foster economic growth and to reduce the poverty level, we must examine the relationship between total foreign aid and gross domestic savings, gross domestic investment, and gross domestic product (GDP) growth rates in Haiti.

\subsection{Background}

The objective of foreign aid is to promote economic development and welfare in recipient countries by providing debt relief, increasing domestic savings, stimulating growth, and reducing poverty levels (Bellone, 2008; Daalgard \& Erickson, 2009; Doucouliagos \& Paldam, 2008; Organization for Economic Co-operation and Development [OECD], 2007). Developing and underdeveloped countries do not have sufficient funds to investment in both capital goods and social and human development projects. Because these countries also have minimal access to international financial markets, they rely heavily on foreign aid as their main source of foreign capital (Chervin \& Wijnbergen, 2010; Dhasmana, 2010; Radelet, 2006). Thus, foreign aid has become a significant source of income for developing countries.

After World War II, foreign aid to such nations increased substantially. Wealthy nations have transferred more than US $\$ 1$ trillion to Africa since 1960 (Ekanayake \& Chatrna, 2010; Moyo, 2009). The average amount of foreign aid to Latin American countries ranged from US $\$ 8$ billion per year in the first half of the 1980s to $\$ 24$ billion in 1990 to $\$ 41$ billion in 1991 (Hachicha, 2003). Between 2001 and 2004, the total amount of foreign aid for developing and underdeveloped countries rose to an estimated $\$ 78.6$ billion (Erixon, 2005). From 1998 to 2007, foreign aid to Haiti amounted to $\$ 3.5$ billion, with an addition $\$ 5$ billion in remittances.

\subsection{Objectives of the Study}

The main goal of increased foreign aid to Haiti has been to reduce the poverty level of the most vulnerable sectors of the Haitian population by increasing the country's economic growth rates and productive capacity through jobs creation, consumption level, and improved human and social services (Bazin, 2008; Buss \& Gardner, 2008). Poverty in Haiti is the highest in the region and is comparable to rates in the poorest African countries (Sletten \& Egset, 2004). Over 80\% of the Haitian population lives below the poverty level, living on less that US $\$ 2$ per day. Of this group, $49 \%$ live in absolute poverty (Verner, 2008), living on less than US \$1 per day (Maxell, 1999).

Haiti has received more than $\$ 4$ billion dollars in direct aid since 2000; yet no visible economic growth has occurred, and living conditions for most Haitians have continued to deteriorate. The country has remained one of the most underdeveloped nations in the Western hemisphere, with the lowest per capita income, the highest child mortality rate, the highest illiteracy rate, and the lowest life expectancy rate in the region (Diego, 2010; McNulty, 2011).

Domestic savings, the backbone of investment, is a determining factor of economic growth. Nearly all nations gear their policies to achieving sustainable economic growth yearly. In general, higher domestic savings and domestic investment rates are predictors of higher GDP growth. However, the contribution of foreign aid to economic growth through gross domestic savings and gross domestic investment is complex, usually occurring over a long period of time. In most empirical studies of the effects of foreign aid on the savings, investment, and economic growth of developing countries, researchers have not accounted for the time involved, focusing instead on the short-term effects of foreign aid on recipient countries (Clemens, Radelet, \& Bhavnani, 2004). To understand the long-term effects of foreign aid, we must consider the lag time, the interval between receipt of the foreign aid and its results.

\section{Methodology of Study}

The present study was a nonexperimental, archival, correlational study conducted to examine the effects of foreign aid on the Haitian economy between 1975 and 2010 in terms of gross domestic savings, gross domestic investment, and GDP growth rates. The predictor variable was the total foreign aid received, disaggregated into grants and concessional loans. The outcome variables were the amounts of gross domestic savings, gross domestic investment, and GDP growth rates. Per capita income, interest rates, and inflation rates were the covariates used to evaluate gross domestic savings and gross domestic investment. Consumption, gross domestic investment, government spending, and net trade balance were the covariates used to evaluate GDP growth rates.

\subsection{Data Collection}

The OECD (2011) database was the source of all data for total foreign aid. Data for GDP growth rates, consumption, gross domestic savings, gross domestic investment, total exports, total imports, interest rates, and inflation rates were drawn from the editions of the International Financial Statistics Yearbook (IFSY, 1989; 2011) published by the International Monetary Fund, and the World Bank Database. All data were in the public domain. Because the effects of foreign aid on economic growth occur over time (Bordo \& Meissner, 2009; Miniou \& Reddy, 2009), lag times of 3, 4, and 5 years were employed in this study.

\subsection{Data Analysis}


Data analyses consisted of examining of statistical records for foreign aid, grants, and concessional loans from 1970 to 2010 and for all other variables from 1975 to 2010, one for each baseline year. Each set of outcome variables (dependent variables) was examined for foreign aid, grants, and loans for lag times of 3 years, 4 years, and 5 years. For example, for the baseline year 1975, analyses involved data from 1972 (3-year lag), 1971 (4-year lag), and 1970 (5-year lag).

Multiple linear regression analyses were conducted using SPSS (version 19) statistical software. A 95\% confidence level was used for all research questions. Residual plots using OLS regression analysis were created to test for nonlinearity in the data. Distribution of data, frequency histograms, and P-P plots of regression residuals standardized residuals were used to test for normality, linearity, and equality of variances. Because the distributions of all the data were normal, parametric statistics were used to analyze data with unequal variances.

To determine the relationship of foreign aid to gross domestic savings and gross domestic investment after correcting for covariates, weighted least squares analyses were performed to correct for unequal variances. To determine the relationship of foreign aid to GDP growth rates after correcting for covariates, ordinary least squares regression analyses were performed.

An a priori power analysis was conducted to determine the minimum sample size for conducting a multiple regression analysis with five and six predictors. Using a large effect size $\left(\rho^{2}=.35\right)$ for a two-tailed test, a desired power of .80 , and an assumed alpha probability of .05 with five predictor variables, a minimum sample size of 63 records was required. For six predictors, a minimum sample of 67 records was required, using G*Power 3.1.4 (Buchner, Erdfelder, Faul, \& Lang, 2007).

\section{Analysis and Interpretations of Findings}

\subsection{Descriptive Statistics}

Table 1 shows the distributions of the variables used for this study. Data drawn from the IMF and World Bank databases have been reported in Haitian gourdes. Data for total foreign aid, grants, and concessional loans were extracted in U.S. dollars and then converted into Haitian gourdes using the annual average exchange rates between the U.S. dollar and Haitian gourdes. Exchange rates data were derived from the IFSYs, published by the IMF. An examination of the intercorrelations of all predictor variables revealed no evidence of multicollinearity, defined as an intercorrelation exceeding .90 (Tabachnick \& Fidell, 2007).

Grant money increased in Haiti between 1970 and 2007. Concessional loan money did not show a similar increase, although the pattern included both positive and negative spikes. Figure 1 and Figure 2 show the changes in grant money and concessional loan money, respectively, over the study period.

Table 1. Descriptive Statistics of Variables

\begin{tabular}{|c|c|c|c|}
\hline Variable & Unit & Range & $M(S D)$ \\
\hline Grants, 3-yr. lag & $\mathrm{HG}^{\mathrm{a}}$ (millions) & {$[26.92,13,554.56]$} & $2,951.98(3,945.50)$ \\
\hline Grants, 4-yr. lag & $\mathrm{HG}^{\mathrm{a}}$ (millions) & {$[23.29,13,554.56]$} & $2,909.49(3969.17)$ \\
\hline Grants, 5-yr. lag & $\mathrm{HG}^{\mathrm{a}}$ (millions) & {$[21.20,12,263.43]$} & $2,553.56(3,551.00)$ \\
\hline Concessional loans, 3-yr. lag & $\mathrm{HG}^{\mathrm{a}}$ (millions) & {$[-925.52,1,996.20]$} & $51.35(393.76)$ \\
\hline Concessional loans, 4-yr. lag & $\mathrm{HG}^{\mathrm{a}}$ (millions) & {$[-925.52,1,996.20]$} & $39.45(388.47)$ \\
\hline Concessional loans, 5-yr. lag & $\mathrm{HG}^{\mathrm{a}}$ (millions) & {$[-925.52,1,996.20]$} & $36.70(388.36)$ \\
\hline Gross domestic savings & $\mathrm{HG}^{\mathrm{a}}$ (millions) & {$[5.80,75.38]$} & $27.07(16.58)$ \\
\hline Gross domestic investment & $\mathrm{HG}^{\mathrm{a}}$ (millions) & {$[10.61,85.97]$} & $29.38(17.73)$ \\
\hline $\mathrm{GDP}^{\mathrm{b}}$ growth rate & Percentage & {$[-50.73,232.15]$} & $18.02(41.17)$ \\
\hline Interest rates & Percentage & {$[0.16,16.70]$} & $5.11(4.57)$ \\
\hline Inflation rates & Percentage & {$[3.28,42.56]$} & $14.33(8.29)$ \\
\hline Consumption & $\mathrm{HG}^{\mathrm{a}}$ (millions) & {$[3,149.00,320,973.00]$} & $65,778.98(86,882.76)$ \\
\hline Government spending & $\mathrm{HG}^{\mathrm{a}}$ (millions) & {$[517.50,320,973.00]$} & $38,606.16(88,054.43)$ \\
\hline Per capita income & $\mathrm{HG}^{\mathrm{a}}$ & {$[744.10,26,862.74]$} & $7,327.02(8,307.96)$ \\
\hline Net trade balance & $\mathrm{HG}^{\mathrm{a}}$ (millions) & {$[-72,472.70,75,870.60]$} & $5,801.35(28,232.70)$ \\
\hline
\end{tabular}


$N=36$.

${ }^{\mathrm{a}} \mathrm{HG}=$ Haitian gourdes; ${ }^{\mathrm{b}} \mathrm{GDP}=$ gross domestic product.

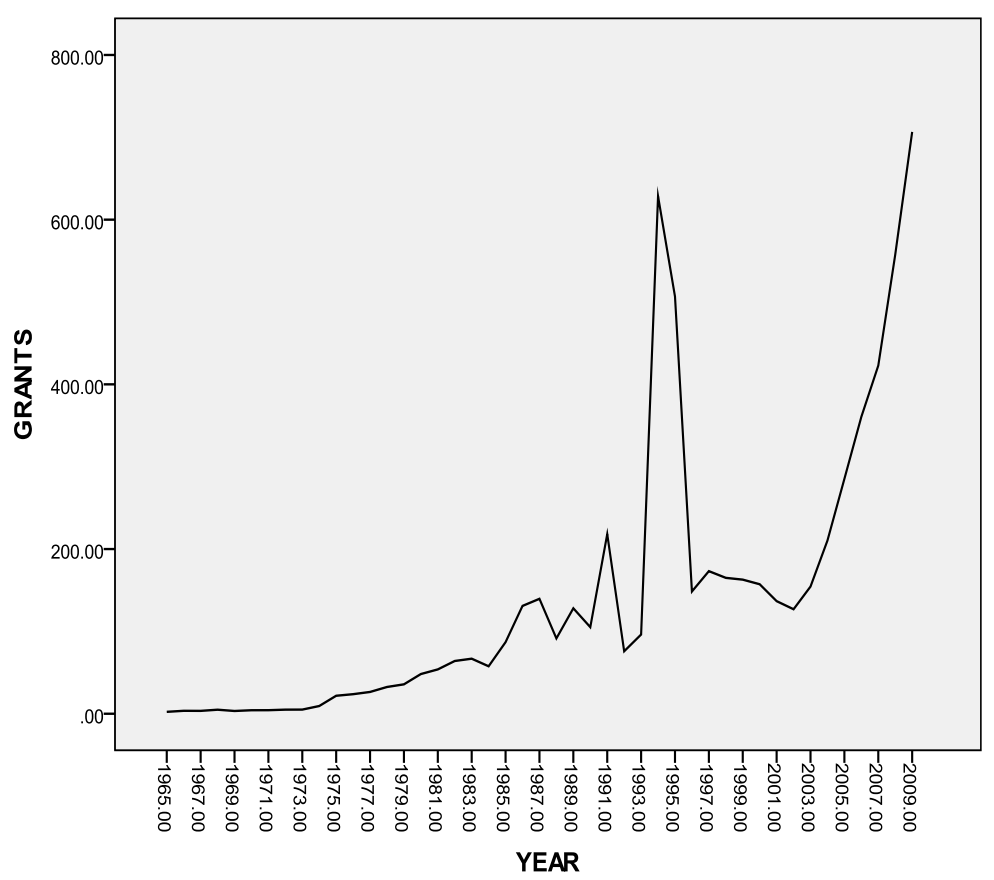

Figure 1. Grants to Haiti, 1965 to 2010.

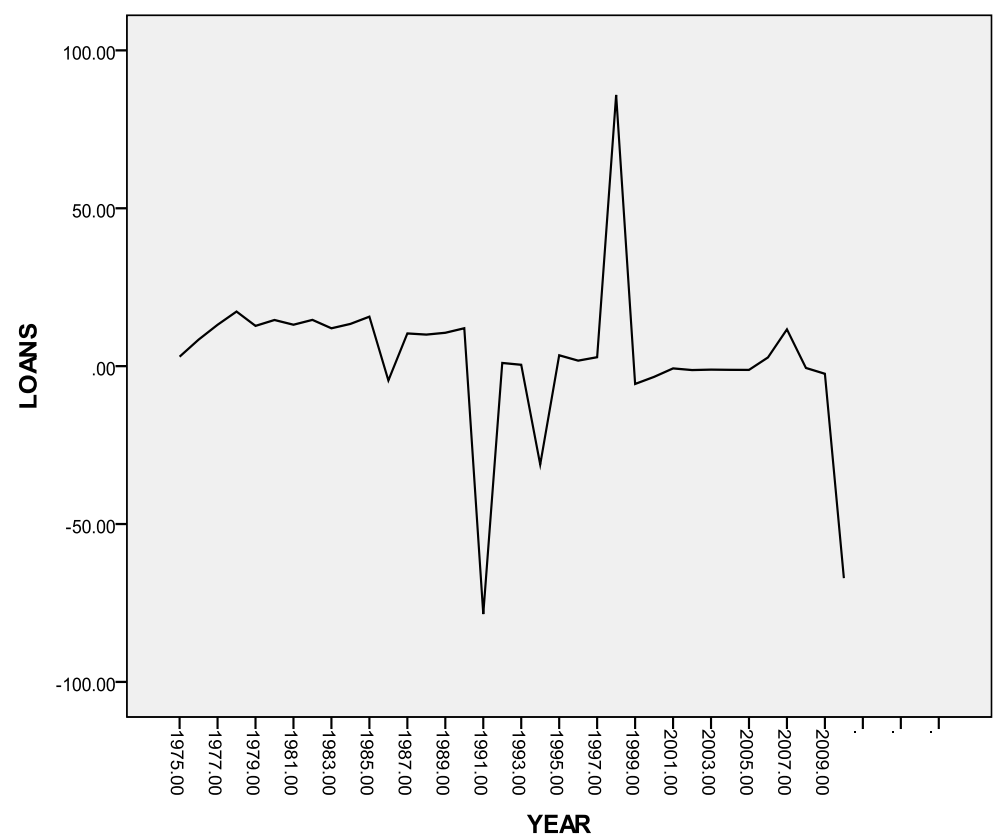

Figure 2. Concessional loans to Haiti, 1975 to 2010.

\subsection{Analysis and Interpretation of Results}

\subsubsection{Multiple Regressions: Foreign Aid and Gross Domestic Savings}

To determine the effect of foreign aid on gross domestic savings, multiple regressions, residual plots, frequency histograms, and P-P plots of regression residuals standardized residuals were conducted. Table 2 shows the intercorrelations of all predictor variables for each lag period. All were below the multicollinearity threshold of .90 . Thus, no intercorrelations existed between any of the predictor variables. 
Analysis showed the distributions to be normal and linear, but the variances were unequal. Therefore, weighted least square regression analyses were performed to correct for this irregularity (Neter, Michael, William, \& Christopher, 1996) and to examine the relationship between foreign aid (disaggregated as grants and concessional loans) and gross domestic savings after accounting for per capita income, interest rates, and inflation rates for each lag period.

Table 2. Intercorrelations of Grants, Concessional Loans, Per Capita Income, Interest Rates, and Inflation Rates

\begin{tabular}{lcccc}
\hline \multicolumn{1}{c}{ Measure } & Grants & Concessional loans & Per capita income & Interest rates \\
\hline Concessional loans & $-.72 * * *$ & 3-year lag & & \\
Per capita income & $.71^{* * *}$ & -- & -- & \\
Interest rates & $.38^{*}$ & .07 & .22 & -- \\
Inflation rates & -.03 & -.27 & -.08 & $.41^{*}$ \\
& & $4-$ year lag & & \\
Concessional loans & $-.72 * * *$ & - & & \\
Per capita income & $.78 * * *$ & .00 & -22 & $-41^{*}$ \\
Interest rates & .26 & -.06 & -.08 & \\
Inflation rates & -.20 & -.26 & & \\
& & $5-$ year lag & & \\
Concessional loans & -.72 & - & -22 & - \\
Per capita income & $.72 * * *$ & .02 & -.08 & $.41^{*}$ \\
Interest rates & .28 & .22 & & \\
Inflation rates & -.19 & .19 & & \\
\hline
\end{tabular}

$N=36$ for each lag-time period

$* p<.05$

$* * * p<.001$

Table 3 shows the results for gross domestic savings. For the 3 -year period, adjusted $R^{2}=.04, F(5,35)=1.32, p=.28$. For the 4-year period, adjusted $R^{2}=.03, F(5,30)=1.24, p=.32$. For the 5-year period, adjusted $R^{2}=.10$, $F(5,30)=1.78, p=.15$. Therefore, the overall relationship between foreign aid and gross domestic savings was not significant for any of the three lag periods. However, interest rate was a significant predictor of the outcomes for the 4-year lag-time period, $p=.04$, and for the 5-year lag-time period, $p=.01$.

Table 3. Predictors of Gross Domestic Savings

\begin{tabular}{|c|c|c|c|}
\hline Variable & $\beta^{\mathrm{a}}$ & $B(S E)$ & $P$ \\
\hline \multicolumn{4}{|c|}{ 3-year lag } \\
\hline Constant & - & $39.44(6.47)$ & $<.001$ \\
\hline Per capita income & -.26 & $0.00(0.00)$ & .27 \\
\hline Interest rate & -.42 & $-0.71(0.39)$ & .08 \\
\hline Inflation rate & -.12 & $-0.14(0.24)$ & .57 \\
\hline Grants (3-yr. lag) & -.11 & $0.00(0.00)$ & .61 \\
\hline Concessional loans (3-yr. lag) & .09 & $0.00(0.00)$ & .64 \\
\hline Adjusted $\mathrm{R}^{2}$ & $\begin{array}{c}.04, \mathrm{~F}(5,30)=1.32 \\
\text { 4-year lag }\end{array}$ & & .28 \\
\hline Constant & - & $36.25(6.86)$ & $<.001$ \\
\hline Per capita income & -.22 & $.00(.00)$ & .32 \\
\hline Interest rate & -.47 & $-.92(.43)$ & .04 \\
\hline Inflation rate & .03 & $.04(.33)$ & .91 \\
\hline Grants (3-yr. lag) & .09 & $.00(.00)$ & .74 \\
\hline Concessional loans (3-yr. lag) & -.01 & $.00(.00)$ & .94 \\
\hline Adjusted $\mathrm{R}^{2}$ & $\begin{array}{c}.03, \mathrm{f}(5,30)=1.24 \\
\text { 5-year lag }\end{array}$ & & .32 \\
\hline Constant & - & $39.91(6.56)$ & $<.001$ \\
\hline Per capita income & -.26 & $0.00(0.00)$ & .19 \\
\hline Interest rate & -.58 & $-1.19(0.46)$ & .01 \\
\hline Inflation rate & -.01 & $-0.01(0.30)$ & .97 \\
\hline Grants (3-yr. lag) & .07 & $-.00(0.00)$ & .74 \\
\hline Concessional loans (3-yr. lag) & .30 & $0.00(0.00)$ & .13 \\
\hline Adjusted $\mathrm{R}^{2}$ & $.10, F(5,30)=1.78$ & & \\
\hline
\end{tabular}


$N=36$

${ }^{\text {a }}$ Standardized coefficients

3.2.2 Multiple Regressions: Foreign Aid and Gross Domestic Investment

In terms of the relationship between foreign aid and gross domestic investment for 3-, 4-, and 5-year lag periods, the predictor variables were identical to those for gross domestic savings (see Table 2). Thus, the intercorrelations of all predictor variables were below the multicollinearity threshold of .90 . Multiple regression analyses, frequency histograms, and P-P plots of the regression residuals standardized residuals revealed distributions were normal and linear but variances were unequal. Therefore, weighted least square regression analyses were used to correct for this irregularity (Neter et al., 1996) and to examine the relationship between foreign aid (disaggregated as grants and concessional loans) and gross domestic investment after accounting for per capita income, interest rates, and inflation rates.

Table 4 shows the results for gross domestic investment. For the 3-year lag, adjusted $R^{2}=.07, F(5,30)=1.49, p=.22$. For the 4-year lag, adjusted $R^{2}=.09, F(5,30)=1.73, p=.16$. For the 5-year lag, adjusted $R^{2}=.16, F(5,30)=2.29$, $p=.07$. Therefore, the overall relationship between foreign aid and gross domestic investment was not significant. However, interest rate was a predictor of the outcomes for the 3-year $(p=.04)$, 4-year $(p=.04)$, and 5-year $(p=.02)$ lag periods. In addition, per capita income was a predictor of the outcome $(p=.01)$ for the 5-year lag period.

Table 4. Predictors of Gross Domestic Investment

\begin{tabular}{|c|c|c|c|}
\hline Variable & $\beta^{\mathrm{a}}$ & $B(S E)$ & $P$ \\
\hline \multicolumn{4}{|c|}{ 3-year lag } \\
\hline Constant & - & $39.91(6.47)$ & $<.001$ \\
\hline Per capita income & -.39 & $0.00(0.00)$ & .10 \\
\hline Interest rate & -.48 & $-0.89(0.42)$ & .04 \\
\hline Inflation rate & .07 & $0.09(0.26)$ & .73 \\
\hline Grants (5-yr. lag) & -.08 & $0.00(0.00)$ & .71 \\
\hline Concessional loans (5-yr. lag) & .14 & $0.00(0.00)$ & .48 \\
\hline Adjusted $\mathrm{R}^{2}$ & $.07, \mathrm{~F}(5,30)=1.49$ & & .22 \\
\hline \multicolumn{4}{|c|}{ 4-year lag } \\
\hline Constant & - & $41.05(7.29)$ & $<.001$ \\
\hline Per capita income & -.42 & $0.00(0.00)$ & .06 \\
\hline Interest rate & -.51 & $-.088(0.40)$ & .04 \\
\hline Inflation rate & .09 & $0.10(0.32)$ & .75 \\
\hline Grants (5-yr. lag) & -.16 & $0.00(0.00)$ & .55 \\
\hline Concessional loans (5-yr. lag) & -.06 & $-.00(0.00)$ & .76 \\
\hline Adjusted $\mathrm{R}^{2}$ & $.09, f(5,30)=1.73$ & & .16 \\
\hline \multicolumn{4}{|c|}{ 5-year lag } \\
\hline Constant & - & $44.16(7.09)$ & $<.001$ \\
\hline Per capita income & -.58 & $-0.00(0.00)$ & .01 \\
\hline Interest rate & -.63 & $-1.14(0.44)^{*}$ & .02 \\
\hline Inflation rate & .10 & $0.12(0.29)$ & .68 \\
\hline Grants (5-yr. lag) & -.01 & $0.00(0.00)$ & .98 \\
\hline Concessional loans (5-yr. lag) & .33 & $0.01(0.00)$ & .10 \\
\hline Adjusted $\mathrm{R}^{2}$ & $.16, \mathrm{~F}(5,30)=2.29$ & & .07 \\
\hline
\end{tabular}

$N=36$

${ }^{\text {a }}$ Standardized coefficients

\subsubsection{Multiple Regressions: Foreign Aid and GDP Growth Rates}

Table 5 shows the intercorrelations of all predictor variables for foreign aid and GDP growth rates in Haiti from 1970 to 2010. All were below the multicollinearity threshold of .90 . Therefore, no intercorrelations existed among the study predictor variables and covariates. 
Table 5. Intercorrelations of Grants, Concessional Loans, Gross Domestic Investment, Government Spending and Net Trade Balance

\begin{tabular}{|c|c|c|c|c|c|}
\hline Measure & Grants & Concessional loans & Consumption & $\mathrm{GDI}^{\mathrm{a}}$ & Government spending \\
\hline & & 3-year lag & & & \\
\hline Concessional loans & $-.72 * * *$ & - & & & \\
\hline Consumption & $.65 * * *$ & .09 & - & & \\
\hline $\mathrm{GDI}^{\mathrm{a}}$ & -.10 & .07 & -.10 & - & \\
\hline Government spending & $.55^{* *}$ & .06 & $.91 * * *$ & -.08 & - \\
\hline Net trade balance & .07 & $\begin{array}{c}-.16 \\
\text { 4-year lag }\end{array}$ & $-.48 * *$ & .03 & $-.53 * *$ \\
\hline Concessional loans & $-.72 * * *$ & - & & & \\
\hline Consumption & $.78 * * *$ & .00 & - & & \\
\hline $\mathrm{GDI}^{\mathrm{a}}$ & -.09 & .03 & -.10 & - & \\
\hline Government spending & $.69 * * *$ & -.04 & $.91 * * *$ & -.08 & - \\
\hline Net trade balance & $-.46 * *$ & $\begin{array}{c}-.02 \\
\text { 5-year lag }\end{array}$ & $-.48 * *$ & .03 & $-.53 * *$ \\
\hline Concessional loans & $-.72 * * *$ & - & & & \\
\hline Consumption & $.72 * * *$ & .02 & - & & \\
\hline $\mathrm{GDI}^{\mathrm{a}}$ & -.06 & .05 & -.10 & — & \\
\hline Government spending & $.59 * * *$ & -.07 & $.91 * * *$ & -.08 & - \\
\hline Net trade balance & $-.46 * *$ & .06 & $-.48 * *$ & .03 & $-.53 * *$ \\
\hline
\end{tabular}

$N=36$.

${ }^{\mathrm{a}} \mathrm{GDI}=$ gross domestic investment

$* * p<.01 ; * * * p<.001$

Visual analysis of the data showed the presence of an outlier. The value of GDP growth rates for 1994 was more than 20 times the median value of 11.26 and more than 4 times the value of the next highest number. The outlier was therefore reduced to 56.67, or one unit higher than the highest value (55.67) for the variable in the database (Tabachnick \& Fidell, 2007). This transformed value was used in the data analyses for all three outcome variables.

The same statistical tests were also applied. The distribution of scores was normal and linear; variances were equal. Table 6 shows the results for GDP growth. For the 3 -year lag period, adjusted $R^{2}=.00, F(6,29)=1.00, p=.44$. For the 4-year period, adjusted $R^{2}=.02, F(6,29)=1.11, p=.38$. For the 5-year period, adjusted $R^{2}=-.03, F(6,30)=0.83$, $p=.56$. Therefore, no significant relationships existed between foreign aid and growth in GDP for any of the three lag-time periods.

Table 6. Predictors of Gross Domestic Product Growth Rates

\begin{tabular}{lcrr}
\hline \multicolumn{1}{c}{ Variable } & $\beta^{\mathrm{a}}$ & $B(S E)$ & $P$ \\
\hline Constant & 3-year lag & & \\
Consumption & - & $21.41(7.69)$ & .009 \\
Gross domestic investment & .35 & $0.00(0.00$ & .48 \\
Government spending & -.29 & $-0.33(0.19)$ & .10 \\
Net trade balance & -.43 & $0.00(0.00)$ & .33 \\
Grants (3-yr. lag) & .03 & $0.00(0.00)$ & .89 \\
Concessional loans (3-yr. lag) & .02 & $0.00(0.00)$ & .94 \\
Adjusted $R^{2}$ & -.20 & $-0.00(0.00)$ & .26 \\
& $.00, \mathrm{~F}(6,29)=1.00$ & & .44 \\
Constant & 4 -year lag & & \\
Consumption & - & $22.08(7.55)$ & .007 \\
Gross domestic investment & .50 & $0.00(0.00)$ & .41 \\
Government spending & -.30 & $-0.34(0.19)$ & .08 \\
Net trade balance & -.49 & $0.00(0.00)$ & .27 \\
Grants (3-yr. lag) & .02 & $0.00(0.00)$ & .92 \\
Concessional loans (3-yr. lag) & -.12 & $-0.00(0.00)$ & .72 \\
Adjusted $R^{2}$ & -.24 & $-0.01(0.01)$ & .17 \\
& $.02, \mathrm{~F}(6,29)=1.11$ & & .38 \\
Constant & 5 -year lag & & \\
Consumption & - & $22.04(7.74)$ & .008 \\
\hline & .55 & $0.00(0.00)$ & .39 \\
\hline
\end{tabular}




\begin{tabular}{lcrc}
\hline Gross domestic investment & -.31 & $-.035(0.20)$ & .08 \\
Government spending & -.49 & $0.00(0.00)$ & .31 \\
Net trade balance & -.03 & $0.00(0.00)$ & .88 \\
Grants (3-yr. lag) & -.18 & $-0.00(0.00)$ & .56 \\
Concessional loans (3-yr. lag) & .06 & $0.00(0.01)$ & .77 \\
Adjusted $R^{2}$ & $-.03, \mathrm{~F}(6,29)=0.83$ & & \\
\hline
\end{tabular}

$N=36$

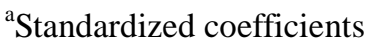

\section{Discussions of Findings, Recommendations, and Conclusions}

With the enactment of the United Nations Millennium Development Goals, endorsed by 189 members in September 2000, foreign development assistance to developing countries to eradicate extreme poverty and hunger increased during the first decade of the 21st century (Dalgaard \& Erickson, 2008). The aim of the Millennium Development Goals was to reduce global poverty by half by 2015 (Moyo, 2009). Foreign aid proponents argued that, to achieve those goals, more foreign aid should go to the least developed countries to raise their standards of living through job creation and increased per-capita income (Mallik, 2008; Riddell, 2008). Advocates of increasing aid also maintained that wealthier countries had not offered enough assistance to poor countries previously (Moyo, 2009).

According to the two-gap model, developing countries need physical capital to invest in development projects and may use foreign aid to compensate for any lack of physical capital (Tarp, 2006). Because of the causal connection between foreign aid, savings, investment, and growth, foreign aid can affect GDP growth rates by easing the saving and investment gaps in developing countries. However, the results from the present study showed that no significant relationship exists between foreign aid and gross domestic savings, gross domestic investment, or GDP growth in Haiti; even though the data analyses indicated some variables were predictive of some of the outcome variables:

1. Interest rate was a predictor of gross domestic savings for both the 4-year lag $(p=.04)$ and the 5-year lag $(p=.01)$ periods.

2. Interest rate was a predictor of gross domestic investment for the 3-year $(p=.04), 4$-year $(p=.04)$, and 5 -year $(p=.02)$ lag periods.

3. Per capita income was a predictor of gross domestic investment for the 5 -year lag period $(p=.01)$.

Neither grants nor concessional loans were predictors of the outcome variables for any of the three lag-time periods studied.

These research findings are consistent with some of the prior research showing foreign aid has no effect on the savings, investment, or growth of recipient countries (Doucouliago \& Paldam, 2006; Mosley, 1987; Rajan \& Subramanian, 2008). Radelet (2006) even argued that foreign aid is detrimental to domestic savings in recipient nations because it results in disincentives to save. However, the literature on the effectiveness of foreign aid in promoting economic development by improving savings, investment, and growth in recipient nations has been inconsistent. For example, a study of the 39 developing countries with the highest inflow of foreign aid between 1985 and 1999 showed foreign aid was negatively related to investment in the recipient nations (Herzer \& Grimm, 2011). A co-integration analysis designed to evaluate the effects of foreign aid on GDP growth rates in the six poorest African countries from 1960 to 1990 showed a positive correlation between foreign aid as a percentage of GDP and real GDP investment in the long run (Mallik, 2008).

The findings from the present study also suggest that increased foreign aid to Haiti may not be a catalyst for reducing poverty. The main purpose of channeling grants and concessional loans to Haiti has been to offset the lack of capital for investment so that development projects would succeed (Bazin, 2006; Buss \& Gardner, 2006). However, foreign aid to Haiti has failed to achieve its purpose of improving the standard of living of the Haitian population (Buss \& Gardner, 2008). Furthermore, this study shows that the failure of foreign aid to increase GDP growth rates in Haiti cannot be attributed simply to insufficient lag time after the influx of foreign aid.

Haiti wastes much of the foreign aid it receives on consumable goods instead of on the promotion of sustainable economic growth and social development. The data suggest that increased foreign aid has been more destructive to the Haitian economy than facilitative in generating productive activities. Since 1975, foreign aid, particularly in the form of grants, has been a contributing factor to negative savings and disinvestment. It has also resulted in reckless government policies and a reliance on foreign aid for Haiti's annual and operating budgets rather than for the formulation and implementation of policies to raise national tax revenue. The findings of this study show that increasing foreign aid to Haiti has been ineffective; there has been no real impact of foreign inflows on saving, investment, and economic growth in Haiti over the period of investigation. Thus, one can conclude that the allocation of foreign to well-formulated and planned development projects coupled with concrete improvements in the management of the funds are needed to see 
an impact from foreign funds on this country's economic performance. We must not, however, interpret the findings of this study to mean that we can withdraw foreign aid from Haiti without serious consequences. Such withdrawal will result in disrupting the implementation of any development projects that do exist, thus, increasing instability. Haiti finances $60 \%$ to $70 \%$ of its national budget through foreign aid in the form of budgetary support (Bazin, 2006). Without foreign aid, the Haitian government will not meet its operating expenses (Buss \& Gardner, 2006). Public employees will not receive their allocations on time, if at all; and public assistance to the most economically needy people will end. Haiti will be at risk for street riots and increased violent crime (Seintenfus, 2010).

Instead, one must view these results as a challenge to longstanding theories regarding the relationship between foreign aid and economic growth through savings and investment in recipient nations. According to both the Harrod-Domar growth model (Bista, 2006) and the gap growth theory (Agrawal \& Sahoo, 2009), the infusion of foreign aid into developing countries facilitates their economic growth. However, in the present study, despite increases in foreign aid grants to Haiti, no such effect occurred between 1975 and 2010.

To reduce poverty, Haiti must experience economic growth. More investment in development programs such as in education, health, agriculture, and social services must occur that will result in higher growth rates and equitable income distribution. Such investment does not necessarily mean more foreign aid. Rather, it means employing better strategies to channel existing foreign aid money into sustainable development projects. Better strategies should result in increased economic growth rates in Haiti not only in the short term but also in the medium and long terms.

Therefore, new ways to allocate foreign aid are needed, along with new methodologies to assess the contributions of foreign aid to the economic development of recipient nations, including investigating the relationship between foreign aid and government investment in development programs in recipient nations. We must also look to reforming foreign aid, shifting the discussion from the issue of whether foreign aid to developing countries is effective to the issue of how to make foreign aid more efficient. For the effectiveness of foreign development assistance depends on the efficient allocation of the aid money.

\section{References}

Agrawal, P., \& Sahoo, P. (2009). Savings and growth in Bangladesh. The Journal of Developing Areas, 42, 89-110.

Bazin, M. L. (2008). Des ideas pour l'action. Port-au-Prince, Haïti: L'Imprimeur II.

Bellone, F. (2008). The role of domestic savings in outward-oriented growth strategies. Journal of Evolutionary Economics, 18, 183-199. http://dx.doi.org/:10.1007/s00191-007-0083-3

Bista, R. (2006). Foreign aid policy and its economic growth effect in Nepal. Economics and Business Journal, 3(1), 109-141.

Bordo, M. D., \& Meissner, C. M. (2007). Foreign capital and economic growth in the era of globalization, National Bureau of Economic Research Working Paper. http://www.nber.org/papers /w13577

Buchner, A., Erdfelder, E., Faul, F., \& Lang, A. G. (2007). G*Power 3: A flexible statistical power analysis program for the social, behavioral, and biomedical sciences. Behavior Research Methods, 39, 175-191.

Buss, T., \& Gardner, A. (2008). Haiti in the balance: Why foreign aid has failed and what we can do. Washington, DC: Brookings Institution Press.

Chervin, M., \& Wijnbergen, S. V. (2010). Economic growth and the volatility of foreign aid (Discussion Paper TI 2010-002/2). Amsterdam, Holland: Tinbergen Institute.

Clemens, M. A., Radelet, S., \& Bhavnani, R. (2004). Counting chickens when they hatch: The short-term effect of aid on growth, 24. Washington, DC: Center for Global Development.

Dalgaard, C. J., \& Erickson, L. (2009). Reasonable expectations and the first millennium development goal: How much can aid achieve? World Development, 37, 1170-1181. http://dx.doi.org/:1016/j.worlddev.2008.11.003

Dhasmana, A. (2010). Welfare gains of aid indexation in small open economies. The Developing Economies, 48, 247-276. http://dx.doi.org//abs/10.1111/j.1746-1049.2010.00107.x

Diego, N. M. (2010). The general ineffectiveness of foreign aid: A look at poverty reduction. http://sb.cofc.edu/pv_obj_cache/pv_obj_id_F17417D767E700C7DFFC7010857C94C39BE90200/filename/The\% 20General\%20Ineffectiveness\%20of\%20Foreign\%20Aid.pdf

Doucouliagos, H., \& Paldam, M. (2006). Aid effectiveness on accumulation: A meta study. Kylos, 59, 227-254. http://dx.doi.org/.10.1111/j.1467-6435.2006.00326.x

Ekanayake. E. M., \& Chatrna, D. (2010, May). The effect of foreign aid on economic growth in developing countries. Journal of International Business and Cultural Studies, 3, 1-13. 
Erixon, F. (2005a). Aid and development: Will it work this time? London, United Kingdom: International Policy Network. http://www.policynetwork.net/development/publication/aid-and-development

Hachicha, N. (2003). Capital inflows-national savings dynamics in Tunisia: Evidence from cointegration, weak exogeneity and simultaneous error correction modeling. International Economic Journal, 17(4), 43-60. http://dx.doi.org/:10.1080/10168730300080026

Herzer, D., \& Grimm, M. (2011). Does foreign aid increase private investment? Evidence from panel cointegration. Applied Economics. http://dx.doi.org/:10.1080/00036846.2011.566183

International Monetary Fund. (1989). International financial statistics yearbook. Washington, DC: International Monetary Fund Press.

International Monetary Fund. (2011). International financial statistics yearbook. Washington, DC: International Monetary Fund Press.

Mallik, G. (2008). Foreign aid and economic growth: A cointegration analysis of the six poorest African countries. Economic Analysis \& Policy, 38, 251-260. http://www.eap-journal.com.au/download.php ?file=675

Maxwell, S. (1999). The meaning and measurement of poverty (ODI Poverty Briefing 3). London, United Kingdom: Overseas Development Institute.

McNulty, B. (2011). The education of poverty: Rebuilding Haiti's school system after its "total collapse." The Fletcher Forum of World Affairs, 35(2), 109-126.

Minoiu, C., \& Reddy, S. G. (2009). Development aid and economic growth: A positive long-run relation, Washington, DC: International Monetary Fund.

Mosley, P. (1987). Overseas aid: Its defense and reform. Sussex, United Kingdom: Harvester.

Moyo, D. (2009). Dead aid: Why aid is not working and how there is a better way for Africa. New York, NY: Farrar, Straus and Giroux.

Neter, J., Michael, K., William, W., \& Christopher, N. (1996). Applied linear statistical models. Mc-Graw-Hill Irwin.Organization for Economic Co-operation and Development (OECD). (2007). Glossary of statistical terms. http://www.stats.oecd.org/glossary/detail.asp?ID=1182

Organization for Economic Co-operation and Development (OECD). (2011). StatDatabase. http://stats.oecd.org /Index.aspx?DatasetCode=TABLE2A

Prokopijevic, M. (2006). Why foreign aid fails (ICER Working Paper Series No. 19). Turin, Italy: International Centre for Economic Research. http://ssrn.com/abstract=945354

Radelet, S. (2006). A primer on foreign aid, Washington, DC: Center for Global Development., 92. http://www.cgdev.org/content /publications/detail/8846/

Rajan, R., \& Subramanian, R. (2008). Aid and growth: What does the cross-country evidence really show? The Review of Economics and Statistics, 90, 643-665.

Riddell, R. (2008). Does aid really work? New York, NY: Oxford University Press.

Seintenfus, R. (2010). Haïti est la prévue de l'échec de l'aide internationale. Interview by Arnaud Robert. AlterPress. http://www.alterpresse.org/spip.php?article10439.

Sletten, P., \& Egset, W. (2004). Poverty in Haiti (Fafo-Paper No. 2004:31). Oslo, Norway: Institute for Labour and Social Research. http://www.mpce.gouv.ht/povertyinhaiti.pdf

Tabachnick, B. G., \& Fidell, L. S. (2007). Using multivariate statistics (5th ed.). Boston, MA: Pearson.

Tarp, F. (2006). Aid and development. Swedish Economic Policy Review, 13, 9-61.

Verner, D. (2008). Making poor Haitians count: Poverty in rural and urban Haiti based on the first households survey for Haiti (Policy Research Group Working Paper Series No. 4571). Washington, DC: World Bank.http://papers.ssrn.com/sol3/papers.cfm?abstract_id=1149074

This work is licensed under a Creative Commons Attribution 3.0 License. 